\title{
Introducing Life to "the Young, the Ignorant, and the Idle": Eliza Haywood and Daniel Defoe as Popular Novelists
}

\author{
Eliza Haywood y Daniel Defoe: novelistas populares
}

\author{
Anaclara CASTRO SANTANA \\ Facultad de Filosofía y Letras, \\ Universidad Nacional Autónoma de México \\ México
}

\begin{abstract}
The remarkable commercial success of the novels of Daniel Defoe and Eliza Haywood in the first few decades of the eighteenth century testifies to a series of cultural phenomena that merit close critical attention. For instance, setting the overwhelming popularity of both writers during their lifetimes in contrast with the scant - though steadily growing — critical recognition accorded to Haywood in our time provides a succinct and vivid illustration of the vagaries of the literary canon. As can be guessed, the snakes and ladders in Defoe and Haywood's game of fame had mostly to do with their gender, as well as with the genre of their most celebrated productions. Ironically, however, for good or evil, their contemporaries tended to put both writers together in the same basket. While professional critics belittled their talents in public — and perhaps envied them in private - the reading public seemed to have an insatiable appetite for their fictions. In short, Haywood and Defoe were fully-fledged popular novelists, with all the positive and negative connotations attached to this label. A key to gauging their place in the history of the novel lies, then, in the type of readers for whom they vied. This article reviews some of the correspondences between Haywood and Defoe - emphasizing their equality in terms of cultural relevance in their own time - with a view to complicate conventional assessments of Defoe as a star novelist and Haywood as a minor writer of amatory fiction, and to encourage reflection about literary practices then and now.
\end{abstract}

Keywords: Daniel Defoe, Eliza Haywood, eighteenth-century novels, popular forms of literature in the eighteenth century, eighteenth-century studies

\section{Resumen}

La exitosa publicación de las novelas de Daniel Defoe y de Eliza Haywood en las primeras décadas del siglo XVIII ejemplifica una serie de fenómenos culturales 
dignos de atenderse. Por ejemplo, la avasallante popularidad de ambos escritores durante su momento histórico, en contraste con la exigua - pero creciente - fama de Haywood en nuestros días, ilustra puntos relevantes sobre las veleidades del canon literario. Como puede inferirse, las ondulaciones en el camino hacia los laureles de ambos escritores se deben en gran parte tanto al género (sexual) de una y otro, como al género (literario) de sus obras narrativas más famosas. Sin embargo, irónicamente tal vez, a ojos de sus contemporáneos Haywood y Defoe eran, para bien o para mal, harina del mismo costal. El público lector devoraba sus obras; la naciente crítica literaria profesional las denostaba en público y quizá envidiaba en privado. En pocas palabras, autora y autor eran novelistas populares, en toda la extensión del término. Una de las claves para entender el lugar que ambos ocupan en la historia de la novela radica, pues, en el tipo de lectoras/ es por quienes competían. En este artículo se revisan algunos puntos de contacto entre Haywood y Defoe, que les sitúan en una relación de equivalencia, en tanto que referentes culturales en su momento histórico, y abren reflexiones sobre el ejercicio literario en nuestro tiempo y el pasado.

Palabras clave: Daniel Defoe, Eliza Haywood, narrativa inglesa dieciochesca, novelistas populares en el siglo XVIII, estudios dieciochescos

1719 might well be considered as an annus mirabilis for the eighteenth-century British novel. It was the year that witnessed the birth of two seminal works of prose fiction in the English language. On April 25, The Life and Strange Surprising Adventures of Robinson Crusoe, of York, Mariner: Who Lived Eight and Twenty Years All Alone in an Uninhabited Island on the Coast of America [...] Written by Himself made its first appearance on the shelves of William Taylor's bookshop on Pater-Noster-Row, from whence it proceeded to inhabit the mantelpieces, tables and chairs of the drawing rooms, libraries, closets, and garrets of its first avid readers (Maslen, 1969: 146-150). That same year (the exact date is not known), Love in Excess; or the Fatal Enquiry was being sold in James Roberts' store in WarwickLane (ESTC, n.d.). Exceedingly popular with book buyers at the time of their publication, these novels left literary legacies that span across generations and nations. ${ }^{1}$ Their esteem in the eyes of critics, and, consequently, their availability for readers, has ebbed and flowed with changing times and sensibilities.

\footnotetext{
${ }^{1}$ Drawing comparisons between Defoe and Haywood's first novels in terms of their commercial success is a contested matter. While assessing sales numbers for Robinson Crusoe is relatively straightforward, it is an issue far more complex in the case of Love in Excess. The main problem lies in the discrepancies there are between the number of editions advertised in the title pages of later reprints and the extant registers of books published in those years. William H. McBurney (1957) famously claimed that Haywood's debut novel sold as much as Robinson Crusoe, making these two, along with Jonathan Swift's Gulliver's Travels, "the most popular English fiction of the eighteenth century before Pamela" (250). In the same vein, Christine Blouch (1991), one of Haywood's first feminist champions, argued that "the total number of editions [of Love in Excess] [...] has been underestimated rather than overestimated" (24-25). In a more recent bibliographical study, however, Patrick Spedding (2004) persuasively shows
} 
Still more famous in our time, Daniel Defoe's Robinson Crusoe has been read from every possible angle, and it has been re-written and rendered into every extant media. 300 years on, the appeal of its novelty has surely extinguished. And yet, as the conference papers, academic articles, monographs, films, videocasts, blogs, and all sorts of cultural manifestations orbiting around literature's most famous castaway that are produced year after year demonstrate, Defoe's novelistic opera prima still raises passions and continues to inspire reactions from readers of all cultural shapes and political sizes. In the words of two recent reviewers, "[Robinson Crusoe] belongs in that small category of classics — others are The Odyssey and Don Quixotethat we feel we've read even if we haven't" (Dirda, 2019), and "Crusoe has joined the likes of Frankenstein's monster, Dracula, Peter Pan and Alice - creations whose fame eclipses that of their creators and have gone on to influence the cultural imagination across the globe" (Sharkey, 2018). Less well-known nowadays, but steadily becoming more so, Love in Excess, and all the subsequent amatory novels of Eliza Haywood, have captivated readers then and now with the psycho-social insights lurking below the seeming triviality of their plots and the convolutedness of their prose. In fact, as will be shown later in this article, the ostensible stylistic shortcomings of Haywood's novels offer a fascinating fusion of form and content. The reputation of Haywood and Defoe as authors has analogously soared and crashed ever since fiction enthusiasts bought their first hardcovers from booksellers' stalls in London - a city that in the early eighteenth century was growing as much in size as in cultural scope and ambition (White, 2013: 1-12).

The resemblances between these authors go beyond their having published their respective first novels in that momentous year. Not only were they able to craft stupendously appealing stories, but they were comparably as prolific and versatile as writers of literary and non-literary genres. Haywood produced around eighty-five original pieces, counting her amorous novels, romans à clef, volumes of poems, translations, periodicals, conduct books, and dramatic criticism (Backscheider, 2010; Blouch, 1998), which rendered her "the most prolific British woman writer of the eighteenth century" (Saxton, 2000: 2). ${ }^{2}$ Defoe, on his part, is credited with having authored some 300 works, including his novels, political satires in prose and verse, moralist tracts, and journalism (Backscheider, 2008). ${ }^{3}$

how Haywood's London publisher William Chetwood deliberately lied about the number of reprints and editions in an attempt to make her novels seem more successful (88). Still, Spedding concedes that "about 6000 copies [of Love in Excess] were published over a 23-year period" (88), a very significant figure by eighteenth-century standards.

${ }^{2}$ Since much of Haywood's fiction was published anonymously or under pseudonyms, the exact number of works written by her is unknown. As with other authors, scholars attempt informed guesses combining internal evidence (mainly typographical and stylistic criteria) and external data (letters between editors and authors, marginalia in first editions, cross-referencing between advertisements and booksellers' records, etc.).

${ }^{3}$ The exact figure is a controversial matter. For a thorough discussion of the history of Defoe attribution see Furbank and Owens (1998: xiv-xx). 
The very fact that modern scholars are unable to determine with certainty the number of titles that each of them actually wrote is yet another point of contact between these two writers, one that is highly revealing about their production methods and marketing ploys, as well as about their target audience and the critical appreciation accorded to both in their own time. In the following pages, a critical excursion will be undertaken, in which points of contact between these ostensibly dissimilar authors will be explored from various perspectives. The proposition that will function as guiding principle of the ensuing discussion is that a useful way of garnering coherence from their seemingly divergent fictions - and the diverse reactions they have generated among as wide a variety of readers over the course of three hundred years - is understanding Defoe and Haywood as popular novelists of their time, who have grown (or dwindled) into canonical ones in our own. A minute consideration of the particularities of this phenomenon, moreover, signals towards intriguing subtexts about the vagaries of taste and trend.

Whether one subscribes, or not, to the theory that the modern British novel emerged in the first half of the eighteenth century-more specifically, according to Ian Watt's (2001) enduringly influential argument, precisely with the publication of Robinson Crusoe - it is hardly deniable that something was taking place in the literary landscape of the 1710s and 1720s, which allowed for a gradual displacing of other forms of popular written entertainment, in favour of longer prose fiction narratives that employed a realistic mode of presentation (be it psychological, as in the case of Haywood, or formal, as in the case of Defoe) (Seager, 2012). The sheer popularity of Defoe and Haywood's narratives, along with those of Mary Davys, Penelope Aubin, and Jonathan Swift, is strong evidence of that (Richetti, 1998; Ballaster, 1992: 32-34). The commercial success of Haywood's Love in Excess, and of the novels that followed, sent an unequivocal signal to others that prose fiction could indeed be a lucrative venture for women writers in England - as it already was in France. This is not to ignore the work undertaken by previous women authors like Aphra Behn and Delarivière Manley, who had written and sold novels over the course of two decades prior to Haywood's first incursion in that genre. As scholars of the early novel have shown, however, the dissemination of Behn and Manley's work pales by comparison with that of Haywood and the women novelists who came after. As Sarah Prescott (2003) points out, "Haywood's success can be said to have changed the face of the marketplace for fiction dramatically. The decade following the publication of Love in Excess saw a remarkable increase in the publication of women's fiction" (106). Similarly, Defoe's best-selling novels of adventures (from Robinson Crusoe to Roxana, passing through Moll Flanders, Colonel Jack, and Captain Singleton) paved the way for other writers of fictional lives and adventures, making it clear that the formula of "formal realism" (Watt, 2001:32) was precisely what modern readers sought. 


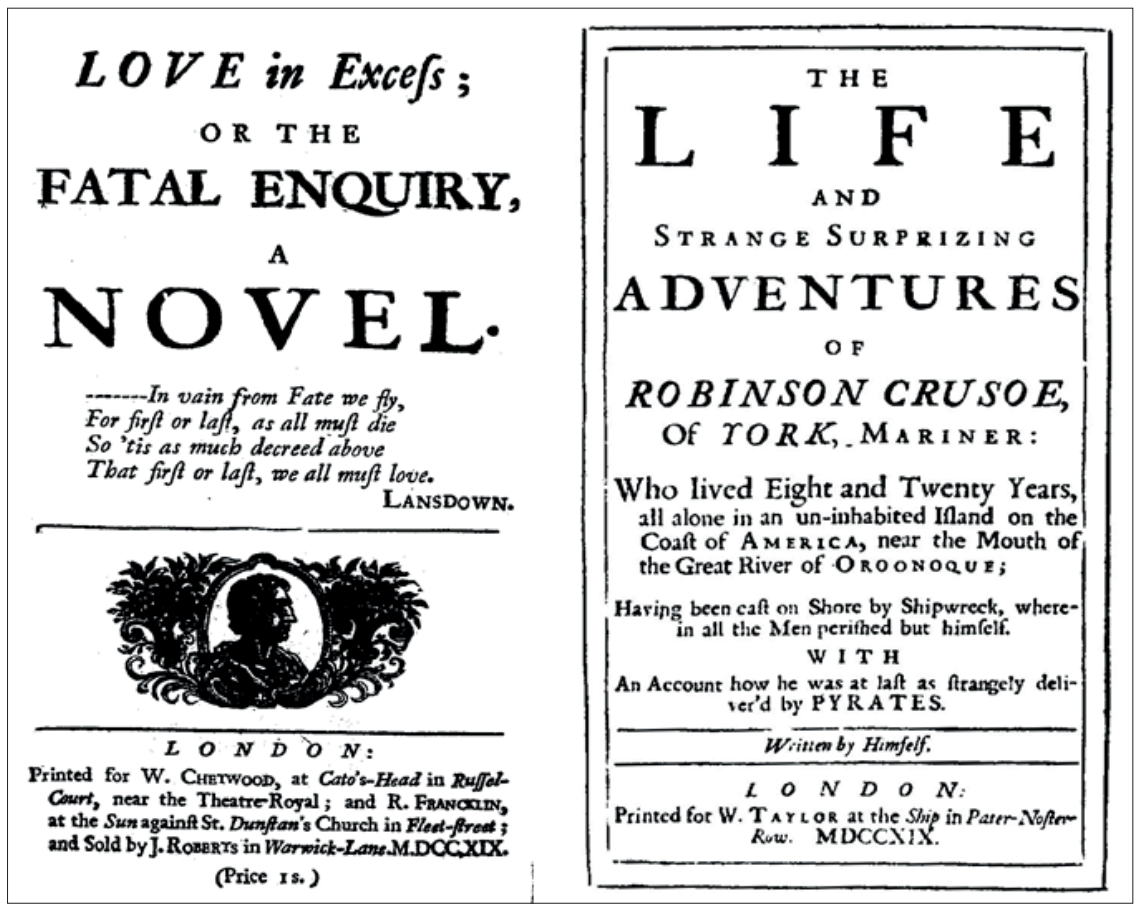

Figure 1. Title pages of the first editions of Haywood and Defoe's first novels

Worthy of attention is that both were published anonymously. Typography lays emphasis on generic affiliations, for marketing purposes. Thus, while Haywood's is "novel" ("a small tale, generally of love", as Johnson's Dictionary of the English Language defined it in 1755), Defoe's is a "life" (a biographical account), full of adventures in remote and exotic locations.

A key to understanding the role that Haywood and Defoe played in this turning point in literary history is having a close look at the public for whom they vied, as well as the expectations that social commentators and literary critics had for the novel as a genre in the early decades of the eighteenth century. This is what will be attempted in the ensuing pages. The notion that, at the threshold modernity, writers of prose fiction were in the midst of discovering and carving a new niche amongst readers - who were, in turn, in the midst of discovering and developing an increasingly voracious appetite for fictional stories grounded in reality - suggests that, for all their ostensible differences in plot choice, writing style, politics, religious views, and ways of living, Haywood and Defoe were one and the same: popular novelists. It is (almost) safe to say that they are not so anymore. While the main plot of Robinson Crusoe continues to be an appealing story, a few years of experience as a student and teacher of eighteenth-century British literature leads me to venture the observation that fewer readers are acquainted with the novel in an unabridged version nowadays; few among them recognize Defoe as the author, and even less would 
consider themselves his admirers. ${ }^{4}$ As mentioned above, Haywood's notability is on the rise. And yet, it is difficult to imagine her works turning into airport-bestsellers. They have paid the inevitable price of ageing. This, nonetheless, is by no means an exercise in nostalgia, but one that touches on the multifariousness of the aspects involved in shaping reading practices and preferences.

\section{Between pleasing and educating readers}

Writing a little more than three decades after the original publication of Haywood and Defoe's first narratives, the celebrated literary scholar and lexicographer Samuel Johnson (1750) described novels as a genre catering to "the Young, the Ignorant, and the Idle, to whom they serve as Lectures of Conduct and Introductions to Life" (n.p). "They are", Johnson continued, "the entertainment of minds unfurnished with ideas, and therefore easily susceptible of impressions; not fixed by principles, and therefore easily following the current of fancy; not informed by experience, and consequently open to every false suggestion and partial account" (Johnson, 1750). This observation was echoed by many others in decades to come. In the latter part of the century, Henry Mackenzie (1785) esteemed that readers of prose fiction were still mainly "the young and the indolent, to whom the exercise of the imagination is delightful" (n. p.). The very real notion (and, to some, the fear) that it was young, and especially female, readers who were consuming the largest volumes of novels was at the heart of the abundant theoretical and practical debates about the subjects and modes of discourse that these texts should employ (Hunter, 1990: 70-88). The apparent hostility that critics such as Johnson and Mackenzie profess against novels in the quotations included above, should not, however, be taken at face value. Like many other critics at the time, both of these authors experimented with and derived handsome profit from novel writing and reviewing.

Johnson's History of Rasselas, Prince of Abissinia (1759), an extended orientalist tale and fictional travelogue, was a minor bestseller in England and the American Colonies. Its ostensibly simple plot - that of an African prince who travels abroad encountering different cultures and societies in a futile search for the secret of human happiness - is laden with philosophical disquisitions that render it similar in theme and scope to Voltaire's Candide, published the same year across the channel, in France. It is rumoured, moreover, that-after the fashion of the Grub-

\footnotetext{
${ }^{4}$ Many causes can be enlisted for this phenomenon. Chief among them, perhaps, are Crusoe's unabashed colonialism, his gleeful endorsement of callous practices such as slave trading, and his racist bias in his imaginary killing of the cannibals and his interactions with Friday, all which, understandably, crash with modern sensibilities. Significantly, many of these passages are either omitted or toned down in abridged versions of the story, especially in youth editions.
} 
Street writers he so enjoyed decrying-Johnson composed this work in a single week in order to raise money to pay for his mother's funeral (Davis, 1999: 7). ${ }^{5}$ Mackenzie, on his part, produced his Man of Feeling (1771), The Man of the World (1773), and Julia de Roubigné (1777) in the latter part of the century, when readers' appetites were steering away from adventure toward the cult of feeling, but the consumers of novels were still mainly young people from the upper and middle classes, who knew how to read and had leisure enough to devote endless hours to that activity on a regular basis. Mackenzie's contributions to The Mirror (17791780) and later to The Lounger (1785-1787) testify not only to his fondness for reading novels, but to the leisure associated with this activity. Johnson also delved into the business of novels by way of criticism, as can be seen in the numerous reviews he published in the periodicals he edited around mid-century: The Rambler (1750-1752), The Adventurer (1753-1754), The Literary Magazine (1756), and The Idler (1758-1760). Worthy of notice are the attributes associated with reading (fiction) that are conveyed by the titles of these publications.

The main point of Johnson and Mackenzie's remarks about the inexperience, naiveté, and idleness of novel readers was not that the genre ought to disappear, but that novelists ought to be prepared to offer morally sound, and easily digestible instruction in their works. In other words, that they should be mindful of the effect of their writing. By implication, then, Johnson's observation also served as a warning against pieces of fiction that could convey the wrong message to the young, impressionable readers that constituted their target audience. This may account, in part at least, for the wane in popularity and sales of Haywood's books towards the last quarter of the eighteenth century, and the near disappearance of her texts from the British canon from the nineteenth century onwards. To squeamish or prudish readers, the amatory adventures of Haywood's characters offer little moral guidance - at least of an explicit kind. The messages of her early novels are very often deliberately ambiguous. Even when the protagonists are punished in the text by parents, legal authorities, or their own bodies, it is unclear whether the behaviours leading to such results - which are narrated with a sense of relish in the transgression-were worthy after all. A caveat regarding craftsmanship is worth introducing here, for, however distasteful to eighteenth-century critics Haywood's moral haziness may have seemed, modern literary theorists such as Umberto Eco have claimed that purposeful uncertainty is a testament to a novelist's artistry (cited in Backscheider, 2000: 23).

A partial exception to Haywood's morally ambiguous novels is one of her last, The History of Betsy Thoughtless, published in 1751. Its title announces a cautionary tale involving a young lady who does not foresee the consequences of her ac-

\footnotetext{
${ }^{5}$ Grub Street was a street in central London associated with impoverished writers who aspired to fame and literary recognition, but who, in the meantime, wrote hastily for money. It was fashionable for more prestigious authors and critics to look down on these so-called "Grub-Street writers".
} 
tions. The notion that it is a "history" attempts to provide a more serious dimension to the text, moving its generic affiliations away from the voyeuristic enjoyment of her early amatory novels. The story contained between the book's covers fulfils the expectations raised by the title. Influenced by the emerging culture of sensibility and the morally serious fiction that Samuel Richardson and Henry Fielding championed around mid-century, as well as by Haywood's own incursions into the genre of conduct literature, Betsy Thoughtless aims to educate a polite young audience, warning female readers about the disadvantages that their status as women conferred upon them in a society rife with sexual double standards. ${ }^{6}$ In this respect, Betsy Thoughtless looks forward to the work of later female novelists, such as Sarah Fielding, Charlotte Lennox, Frances Sheridan, Sarah Scott, Frances Burney, and Jane Austen, all of whom must have read it, given its enormous popularity - with nine editions in English by the end of the century, a few stage adaptations, and translations to French, German, Dutch and Swedish (Spedding, 2004: 529).

Some occurrences in Haywood's biography may also have affected the endurance of her work in the critical landscape. Apart from her being a woman - a fact in itself detrimental for authors in an age of conspicuous misogyny (Rodríguez Álvarez, 2017: 32-33) - social commentators frequently targeted her supposed lack of (sexual) decorum. Writing in 1743, for instance, Lord Egmont pedantically described Haywood as: "a whore in her youth, a bawd in her elder years, and a writer of lewd novels, wherein she succeeded tolerably well" (cited in Hartley, 2003: 436). Egmont was probably alluding to the fact that Haywood had children outside of wedlock, and that, for most of her life, she was a woman living on her own, writing for others who might share her condition. These circumstances clouded her reputation and made it easy for subsequent critics to discard her work as the production of a woman of loose morals, something that was perceived as a danger to the inexperienced and susceptible young readers whom critics such as Johnson identified as the main readership of prose fiction.

By contrast, the fictions of Defoe, chiefly among them Robinson Crusoe, fared far better with literary critics and social commentators on the long run. After all, the story of the entrepreneurial castaway proves to be what in the eyes of British men from the establishment is a useful lesson, or rather a series of useful lessons in endurance, self-reliance, capitalist accumulation of property, patriotism, and colonial expansionism. Never mind that in his own day, Defoe was disparaged by more prestigious writers such as Jonathan Swift and Alexander Pope as a crude

\footnotetext{
${ }^{6}$ While most of Haywood's novels made a point about the frailty of women's reputation in a maledominated world, in Betsy Thoughtless the punishments and rewards meted out convey a far more conservative message, one that links happiness with the preservation of the status quo. Yet, as Backscheider (2000) suggests, before the fairy-tale happy ending, the novel calls attention to the way eighteenth-century women from all social classes and ages were regarded as "above all else, economic units" (39; emphasis in the original), which is a token of Haywood's shrewd subtlety for social criticism.
} 
propagandist, with scant formal education, little sense of humour, with a mercenary pen, and, apparently, no sense of shame. In the words of a modern biographer, they saw him as "an unprincipled man who would write on any side of any question for money" (Backscheider, 2008). Being as much an entrepreneur in the world of trade as in the world of print, Defoe was the quintessential "modern" writer against whom the neoclassicals waged their ideological wars.

The landscape, nonetheless, was not as bleak as all this suggests for Defoe and Haywood in their own time. As conventional wisdom regarding fame has it: the fact that they were vociferously spoken against is incontestable proof of their achievements. In the apt words of David Oakleaf (2000): "in the small, jealous, and intensely political literary scene of Haywood's day, appallingly cruel satire was almost the routine tribute to success" (9). A listing of the appellations that Haywood and Defoe received from their contemporaries illustrates the point brilliantly. In her lifetime Haywood was known as "Mrs Novel"- so Henry Fielding dubbed her in his Author's Farce (1731) - and as "the Great Arbitress of Passion"a label used by James Sterling for the first time in his poem "To Mrs. Eliza Haywood on her Writing," affixed to the third edition of Haywood's Secret Histories, Novels, and Poems (1732). The first epithet was a piece of satire; the second was offered as a genuine commendation. All three of them, however, can receive reverse readings. Sterling's can be interpreted as a backhanded compliment, as much descriptive of Haywood's work, as prescriptive of the types of texts expected of a woman writer. Conversely, styling Haywood as "Mrs Novel" played with the association between gender and genre (i.e. the novel as a mode employed by women), but it also implied that she was the ultimate authority in that field of writing - no small feat at a time when the readership and sales numbers for prose fiction were rapidly growing. Fielding himself would turn to novel writing a decade later, starting with his parodic Shamela (1741), followed by Joseph Andrews (1742), Tom Jones (1748), and Amelia (1751), as well as a far more disreputable (and tantalizing) piece entitled The Female Husband (1746), which combines the picaresque leanings of Defoe with the erotic (and sapphic) boldness of Haywood. Later in the century, critics empathic to Haywood continued to sing her praises in a similarly ambivalent way. Writing eight years after her demise, David Erskine Baker (1764), Haywood's first biographer, described her as "the most voluminous female writer this kingdom has ever produced [... whose] genius lay chiefly in the department of novel writing" (319). By tempering the acknowledgement of Haywood's prolificity with a caveat that implicitly belittles the genre in which she excelled, Baker's famous remark betrays a nervousness that could only have been caused by someone who mattered.

The author of Robinson Crusoe generated similar reactions among his contemporaries and immediate successors. For fellow Grub-Street writers, the mixture of admiration and spite proved a powerful stimulant. Such is the case of Charles Gildon (1719), who, following the publication of Robinson Crusoe, wrote a humor- 
ous dialogue between Defoe and his characters in which Friday and Crusoe assault their maker. Others found Defoe's person and work so threatening to their own practice as writers that they tried to sweep them both under the carpet. Swift, for instance, claimed that Defoe was so "grave sententious, dogmatical a Rogue, that there is no enduring him" (cited in Richetti, 2008: 1). In that same piece, as in various other public remarks, the dean of Saint Patrick's made a point about not even remembering Defoe's name (Rawson, 2014, 76). Yet, his Gulliver's Travels (1726) is indebted to Robinson Crusoe in more ways than one (Rawson, 2014: 67). Similarly, in his History of England (1757-1758), the physician, translator, and novelist Tobias Smollett glossed over Defoe as "a scurrilous party-writer in very little estimation" (cited in Rogers, 2013: 13). This assessment was deliberately inaccurate, given Defoe's popularity with book buyers. Similar to the way critics drew upon Haywood's gender as a way to demean her literary accomplishments, appreciation for Defoe's work was, for a while, plagued by ad hominem attacks targeting the writer's partisanship (in his early years), his puritanical sympathies, and his association with the world of trade. Admittedly, since early on, there were those who eulogized Robinson Crusoe (in spite of its writer), thanks to what they saw as its didactic potential. Chief among them was the French philosopher (and novelist) Jean Jacques Rousseau (1762), who stated that Robinson Crusoe was the first - and for a long time the only-book to be read by Émile, his fictitious ideal pupil (58-66). It would be many decades before Rousseau's views became accepted in England, however, for his reputation in that country was largely negative until the Romantic period. Indeed, according to a modern scholar, Rousseau's "support may have been counter-productive" for Defoe's reputation (Rogers, 2013: 14).

Pope's Dunciad (1728-1742) provides what is perhaps the most illuminating instance of Haywood and Defoe coming together for a dose of malicious bashing. As is the case in all the items that conform Pope's blacklist of cultural buffoons, the personal reputation of Haywood and Defoe is astutely merged (and distorted) with their purported inadequacy at writing. A combination of scandal and mercenary motives for writing earns them a place of honour in the "shaggy Tap'stry" offered by Goddess Dullness as a price for stupidity and avarice in Book II (line 143). Thus, readers of The Dunciad learn that on the foreground of the fabric mural "Earless on high stood unabashed De Foe" (Pope, 2006: line 147). A few lines later, enters "Eliza [Haywood]" with "Two babes of love close clinging to her waste, / Fair as before her works she stands confess'd / In flow'rs and pearls by bounteous Kirkall dressed" (Pope, 2006: 11. 157-161). To the mind of authors like Pope-whose opinions were highly influential in the first half of the eighteenth century —Defoe and Haywood were equally as shameless in their personal lives as in their vying for readers. The popularity of their works, then, was responsible for what authors of Pope's mindset saw as the degradation of taste and literary standards. Ironically, however, in time, tradition, shifts in reading practices, as well as 
ideological and gender biases gradually separated Defoe and Haywood's works, obliterating the fact that, originally, both of them had been considered little more than astute entertainers of the masses, comparable to the way sophisticated students of literature might view popular authors such as J.K. Rowling and John Grisham; or Dan Brown and Suzanne Collins.

According to Pat Rogers (2013), "Defoe the great novelist is an invention of the nineteenth century" (4). In this period, he began to be acknowledged as "an extraordinary man [...] possessed [of] a powerful memory [...] and a no less copious vein of imagination" (Scott, 2013: 67), and a writer whose work "always interests, never agitates" (Coleridge, 2013: 80)-two characteristics that later endeared him to the Victorians. His Robinson Crusoe became celebrated as a work "delightful to all ranks and classes" (Lamb cited in Defoe, 1994: 269). The combination of Christian fervour and prophetic enthusiasm about the expansion of the British empire were probably behind these encomia. Meanwhile, assessments of Haywood, let alone positive ones, are quite hard to come by in nineteenth-century criticism. She was usually mentioned briefly as an "authoress" who "owed her evil reputation to the freedom with which she followed the example of Mrs Manley in introducing into her romances scandals about the leaders of contemporary society, whose names she very thinly veiled" (314), as Sidney Lee (1891) described her in the relevant entry of the first edition of the Dictionary of National Biography.

The twentieth century saw Defoe's heyday, crowning him as the "father of the English novel"- a title bestowed by James Joyce in 1912 (cited in Marsh, 2011: 201) - who regarded Robinson Crusoe as a token of all that was admirable and dreadful about English culture. ${ }^{7}$ Haywood, on her part, was persistently neglected by literary criticism, and her texts for a long time all but disappeared from library and bookshop shelves (Blouch, 1991: 546n2). Although the first modern critical assessment of her works is not as recent as one may think - dating from $1915^{8}$ - the real turn occurred in the 1990s, when the first scholarly editions of her works, the first modern critical biographies, and the first collections of essays about her and her writings were published. ${ }^{9}$ With the inclusion for the first time of Haywood's Fantomina in the sixth edition of the Norton Anthology of English Literature (2006), we can say that her reinstatement on equal footing with Defoe has reached full circle. ${ }^{10}$

\footnotetext{
${ }^{7}$ He suggested as much in a lecture delivered at the Italian Università Popolare Triestina. It was reprinted and circulated in book format half a century later as James Joyce, Daniel Defoe (Buffalo, NY: Buffalo Studies, State University of New York, 1964).

${ }^{8}$ It is a study written by George Whicher, entitled The Life and Romances of Mrs Eliza Haywood, in which the writer's biography is mingled with critical appreciations of her novels.

${ }^{9}$ Examples of these can be found in the works cited throughout this article.

${ }^{10}$ Fantomina is still part of the most recent edition of the Norton Anthology (2018). In previous editions of this anthology, extracts from Roxana were summoned to represent Defoe. The latest edition replaced them for a short extract of Robinson Crusoe, and the Preface from The Farther Adventures of Robinson Crusoe.
} 


\section{Of castaways, pirates, and seduction}

Leaving behind the modest reception history that has been essayed in previous pages, I want to turn now to a brief consideration of the ways in which Defoe and Haywood's work might have influenced one another, or, at least, broadened their interests as writers. An expedient, if perhaps simplistic, way of comparing and contrasting Defoe and Haywood's careers is by examining their chronological bibliographies together. As can be seen in the table below (Table 1), their incursions into fiction seem to follow a contrary path: while Haywood produced most of her novels in her youth, turning to periodicals and advice literature in middle age, Defoe wrote his most famous prose fictions in the winter of his life. All of his novels can be thus regarded as works of maturity - the productions of an experienced man, who saw himself as entitled, and indeed duty-bound, to impart useful lessons to the young, ignorant, and idle readers identified by Johnson as the chief consumers of fiction. Haywood's Love in Excess, and the flurry of novels that followed over the course of the 1720s and 1730s, by contrast, are all energetic apprenticeships in a genre that was equally as young, vibrant and full of potential.

A first point of coincidence having to do with yield and timing stands out between 1719 and 1724, a five-year period in which novel writing was the chief employment of both authors. Beginning with sequels for each of their proven successes, they continued to delve into the possibilities of prose fiction, experimenting with structure, theme, characterization, and motifs. A cursory reading of titles suggests the appeal that purportedly real accounts of individual lives had for the reading public, one which both writers exploited to its fullest. A general review of plots points towards surprise- both in the sense of being "seized with (or of) a desire, emotion, etc., a disease or illness" and of "causing surprise or wonder by its unexpectedness; [or being] astonishingly wonderful" (OED, 2019) - as a crucial element in common between the two novelists. Defoe's fast-paced fictions are all about wonder and astonishment, reflecting in their protagonists' relentless pursuit of adventure their audience's insatiable hunger for novelty and change. As the author declared it in the preface of his first sequel to Robinson Crusoe, "the surprising Variety of the Subject" was one of the main reasons why the public was drawn to the book. Consequently, in the subsequent volume, he promised to deliver "as Strange and surprising Incidents, and as great a Variety of them" as in the original (Defoe, 1994: 239).

The surprise inherent in Haywood's work is related to the first (now obsolete) meaning of the word, that of being suddenly apprehended with or overwhelmed by strong emotion or desire - in a way that body and mind become simultaneously implicated. Her investment in novelty is equally as strong as Defoe's, but it resides in the artful balancing of repetition and innovation, her unique dexterity for concocting seamless (and enriched) pastiches. For instance, to the plots that she transposed from her translations from French and Spanish, she added a layer of the kind of realism that was developing into a norm for prose fiction in her day. Thus, she explored in deeper psychological detail than continental romances did the disastrous consequences that the extreme separation of 
Table 1

\begin{tabular}{|c|c|c|c|}
\hline \multicolumn{2}{|r|}{ Daniel Defoe } & \multicolumn{2}{|r|}{ Eliza Haywood } \\
\hline Type* & Title and date of publication & Type & Title and date of publication \\
\hline NFP & An Essay upon Projects (1697) & $\mathbf{F}$ & Love in Excess (1719) \\
\hline $\mathbf{P}$ & The Pacificator (1700) & $\mathbf{F}$ & Love in Excess vol II (1719) -Sequel- \\
\hline $\mathbf{P}$ & $\begin{array}{l}\text { The True-Born Englishman: A Satire } \\
\text { (1701) }\end{array}$ & $\mathbf{T}$ & $\begin{array}{l}\text { Letters from a Lady of Quality to a } \\
\text { Chevalier (1720) }\end{array}$ \\
\hline NFP & $\begin{array}{l}\text { The History of the Kentish Petition } \\
\text { (1701) }\end{array}$ & $\mathbf{F}$ & Love in Excess vol III (1719) -Sequel- \\
\hline $\mathbf{P}$ & England's Late Jury (1701) & D & The Fair Captive (1721) \\
\hline NFP & $\begin{array}{l}\text { The Shortest Way with the Dissenters } \\
\text { (1702) }\end{array}$ & $\mathbf{F}$ & The British Recluse (1722) \\
\hline NFP & $\begin{array}{l}\text { A new test of the Church of England's } \\
\text { loyalty: or, Whiggish loyalty and } \\
\text { church loyalty compar'd (1702) }\end{array}$ & $\mathbf{F}$ & The Injur'd Husband (1722) \\
\hline & - 42 political pamphlets in prose & $\mathbf{F}$ & $\begin{array}{l}\text { Idalia; or The Unfortunate Mis- } \\
\text { tress (1723) }\end{array}$ \\
\hline $\mathbf{P}$ & A Hymn to the Pillory (1703) & D & A Wife to be Lett (1723) \\
\hline $\mathbf{P}$ & Poems on Affairs of State (1703) & $\mathbf{F}$ & Lasselia; or The Self-Abandon'd (1723) \\
\hline NFP & $\begin{array}{l}\text { An Essay on the Regulation of the } \\
\text { Press (1704) }\end{array}$ & $\mathbf{F}$ & $\begin{array}{l}\text { The Rash Resolve; or, The Untimely } \\
\text { Discovery (1723) }\end{array}$ \\
\hline NFP & Giving Alms No Charity (1704) & $\mathbf{P}$ & Poems on Several Occasions (1724) \\
\hline NFP & The Review (1704 to 1713 ) & $\mathbf{F}$ & A Spy Upon the Conjurer (1724) \\
\hline NFP & $\begin{array}{l}\text { The Consolidator; or, Memoir of } \\
\text { Sundry Transactions from the World } \\
\text { in the Moon (1705) }\end{array}$ & $\mathbf{T}$ & The Lady's Philosopher's Stone (1725) \\
\hline NFP & $\begin{array}{l}\text { A True Relation of the Apparition of } \\
\text { Mrs. Veal (1706) }\end{array}$ & $\mathbf{F}$ & $\begin{array}{l}\text { The Masqueraders; or Fatal Curios- } \\
\text { ity (1724) }\end{array}$ \\
\hline $\mathbf{P}$ & Caledonia (1706) & $\mathbf{F}$ & $\begin{array}{l}\text { The Fatal Secret; or, Constancy in } \\
\text { Distress } \mathbf{( 1 7 2 4 )}\end{array}$ \\
\hline $\mathbf{P}$ & $\begin{array}{l}\text { Jure Divino: A Satyr in Twelve Books } \\
\text { (1706) }\end{array}$ & $\mathbf{F}$ & The Surprise (1724) \\
\hline NFP & $\begin{array}{l}\text { History of the Union of Great Britain } \\
(1709)\end{array}$ & $\mathbf{F}$ & $\begin{array}{l}\text { The Arragonian Queen: A Secret } \\
\text { History (1724) }\end{array}$ \\
\hline
\end{tabular}

*Key: NFP $=$ Non-fictional prose, $\mathrm{P}=$ Poetry, $\mathrm{F}=$ Fiction, $\mathrm{HF}=$ Historical fiction, $\mathrm{T}=$ Translation, $\mathrm{D}$ $=$ Drama 
Table 1. Cont.

\begin{tabular}{|c|c|c|c|}
\hline \multicolumn{2}{|r|}{ Daniel Defoe } & \multicolumn{2}{|r|}{ Eliza Haywood } \\
\hline Type* & Title and date of publication & Type & Title and date of publication \\
\hline NFP & $\begin{array}{l}\text { The Succession of Spain Consider'd } \\
\text { (1711) }\end{array}$ & $\mathbf{F}$ & $\begin{array}{l}\text { The Force of Nature; or, The Lucky } \\
\text { Disappointment (1724) }\end{array}$ \\
\hline NFP & Atalantis Major (1711) & $\mathbf{F}$ & Memoirs of the Baron de Brosse (1724) \\
\hline NFP & $\begin{array}{l}\text { An Essay on the South-Sea Trade } \\
\text { (1712) }\end{array}$ & $\mathbf{T}$ & La Belle Assemblée (1724-1734) \\
\hline NFP & $\begin{array}{l}\text { An Answer to a Question that No } \\
\text { Body Thinks of (But what if the Queen } \\
\text { should die?) (1713) }\end{array}$ & $\mathbf{F}$ & $\begin{array}{l}\text { Memoirs of a Certain Island Adjacent to } \\
\text { the Kingdom of Utopia } \mathbf{( 1 7 2 5 )}\end{array}$ \\
\hline NFP & $\begin{array}{l}\text { An Appeal to Honour and Jus- } \\
\text { tice (1715) }\end{array}$ & $\mathbf{F}$ & $\begin{array}{l}\text { Bath Intrigues: in four Letters to a } \\
\text { Friend in London } \mathbf{( 1 7 2 5 )}\end{array}$ \\
\hline NFP & The Family Instructor (1715) & $\mathbf{F}$ & The Unequal Conflict (1725) \\
\hline $\mathbf{P}$ & A Hymn to the Mob (1715) & NFP & The Tea-Table (1725) \\
\hline NFP & $\begin{array}{l}\text { The Conduct of Christians Made the } \\
\text { Sport of Infidels (1717) }\end{array}$ & $\mathbf{F}$ & $\begin{array}{l}\text { The Dumb Projector: A Surprising Ac- } \\
\text { count of a Trip to Holland Made by Dun- } \\
\text { can Campbell }(1725)\end{array}$ \\
\hline NFP & The Family Instructor. Vol. II (1718) & $\mathbf{F}$ & The Fatal Fondness (1725) \\
\hline $\mathbf{F}$ & $\begin{array}{l}\text { The Life and Strange Surprising Adven- } \\
\text { tures of Robinson Crusoe (1719) }\end{array}$ & $\mathbf{F}$ & Mary Stuart, Queen of Scots (1725) \\
\hline $\mathbf{F}$ & $\begin{array}{l}\text { The Farther Adventures of Robinson Cru- } \\
\text { soe (1719) -Sequel- }\end{array}$ & $\mathbf{F}$ & $\begin{array}{l}\text { The Mercenary Lover; or, the Unfortunate } \\
\text { Heiresses (1726) }\end{array}$ \\
\hline $\mathbf{F}$ & $\begin{array}{l}\text { Serious Reflections of Robinson Crusoe } \\
\text { (1720) -Sequel- }\end{array}$ & $\mathbf{F}$ & $\begin{array}{l}\text { The Distressed Orphan; or, Love in a Mad- } \\
\text { house (1726) }\end{array}$ \\
\hline HF & Memoirs of a Cavalier (1720) & $\mathbf{F}$ & $\begin{array}{l}\text { The City Jilt; or, The Alderman Turn'd } \\
\text { Beau (1726) }\end{array}$ \\
\hline $\mathbf{F}$ & $\begin{array}{l}\text { The Life, Adventures, and Piracies, of } \\
\text { the Famous Captain Singleton (1720) }\end{array}$ & $\mathbf{F}$ & $\begin{array}{l}\text { The Double Marriage; or, The Fatal Re- } \\
\text { lease (1726) }\end{array}$ \\
\hline $\mathbf{F}$ & $\begin{array}{l}\text { The Fortunes and Misfortunes of the } \\
\text { Famous Moll Flanders (1722) }\end{array}$ & & +/- 15 other novels \\
\hline $\mathbf{F}$ & A Journal of the Plague Year (1722) & $\mathbf{T}$ & The Disguis'd Prince (1728) \\
\hline NFP & $\begin{array}{l}\text { Religious courtship: being historical } \\
\text { discourses }(1722)\end{array}$ & D & $\begin{array}{l}\text { Frederick, Duke of Brunswick-Lunen- } \\
\text { burgh (1729) }\end{array}$ \\
\hline $\mathbf{F}$ & History and Remarkable Life of Col & D & The Opera of Operas (1733) \\
\hline
\end{tabular}
Jacques, Commonly Call'd Col Jack (1723)

NFP Tour Through the Whole Island of Great Britain (1724-1727)

NFP The Dramatic Historiographer (1735) 
Table 1. Cont.

\begin{tabular}{|c|c|c|c|}
\hline \multicolumn{2}{|r|}{ Daniel Defoe } & \multicolumn{2}{|r|}{ Eliza Haywood } \\
\hline Type* & Title and date of publication & Type & Title and date of publication \\
\hline NFP & $\begin{array}{l}\text { Everybody's Business is Nobody's } \\
\text { Business (1724-1727) }\end{array}$ & $\mathbf{F}$ & $\begin{array}{l}\text { Adventures of Eovaai, Princess of Ijaveo } \\
(1736)\end{array}$ \\
\hline $\mathbf{F}$ & $\begin{array}{l}\text { The Fortunate Mistress: or, Roxana } \\
\text { (1724) }\end{array}$ & $\mathbf{F}$ & $\begin{array}{l}\text { The Anti-Pamela; or Feign'd Innocence } \\
\text { Detected (1741) }\end{array}$ \\
\hline NFP & $\begin{array}{l}\text { The Complete English Tradesman } \\
\text { (1726) }\end{array}$ & NFP & A Present for a Servant Maid (1743) \\
\hline NFP & $\begin{array}{l}\text { The Political History of the Devil } \\
\text { (1726) }\end{array}$ & $\mathbf{F}$ & The Fortunate Foundlings (1744) \\
\hline NFP & $\begin{array}{l}\text { Conjugal Lewdness: A Treatise Concern- } \\
\text { ing the Use and Abuse of the Marriage Bed } \\
(1727)\end{array}$ & NFP & $\begin{array}{l}\text { The Female Spectator (4 volumes, 1744- } \\
\text { 1746) }\end{array}$ \\
\hline NFP & $\begin{array}{l}\text { Augusta Triumphans: A plan for the Eng- } \\
\text { lish Commerce (1728) }\end{array}$ & NFP & The Parrot (1746) \\
\hline \multirow[t]{10}{*}{ NFP } & $\begin{array}{l}\text { Humble Proposal to the People of Eng- } \\
\text { land, for the Increase of their Trade (1729) }\end{array}$ & $\mathbf{F}$ & Memoirs of a Man of Honour (1747) \\
\hline & & $\mathbf{F}$ & $\begin{array}{l}\text { Life's Progress through the Passions; or, The } \\
\text { Adventures of Natura } \mathbf{( 1 7 4 8 )}\end{array}$ \\
\hline & & NFP & Epistle for the Ladies (1749) \\
\hline & & $\mathbf{F}$ & Dalinda; or The Double Marriage (1749) \\
\hline & & $\mathbf{F}$ & $\begin{array}{l}\text { The History of Miss Betsy Thoughtless } \\
\text { (1751) }\end{array}$ \\
\hline & & $\mathbf{F}$ & $\begin{array}{l}\text { The History of Jemmy and Jenny Jessamy } \\
\text { (1753) }\end{array}$ \\
\hline & & $\mathbf{F}$ & The Invisible Spy (1754) \\
\hline & & NFP & The Wife (1756) \\
\hline & & NFP & The Young Lady (1756) \\
\hline & & NFP & The Husband (1756) \\
\hline \multicolumn{2}{|c|}{ Dies April 24 ${ }^{\text {th }}, 1731$} & \multicolumn{2}{|c|}{ Dies February $26^{\text {th }}, 1756$} \\
\hline
\end{tabular}

*Key: $\mathrm{NFP}=$ Non-fictional prose, $\mathrm{P}=$ Poetry, $\mathrm{F}=$ Fiction, $\mathrm{HF}=$ Historical fiction, $\mathrm{T}=$ Translation, $\mathrm{D}$ $=$ Drama

Selection from Furbank and Owens (1998). A Selections from Blouch, Christina (Ed.) (1998). Critical Biography of Daniel Defoe. London: "Works of Eliza Haywood", in Eliza Haywood's Pickering and Chatto. Betsy Thoughtless. Peterborough: Broadview Press. 
male and female spheres among the middle and affluent classes had for both men and women during courtship and marriage. Like the protagonists of Defoe and their unyielding quest for adventure, the women and men that populate the pages of a Haywood novel seem perennially on the search for more and surprising ways of seducing, being seduced, and giving vent to their desires.

Intriguingly, while the writing styles and moral agendas of Haywood and Defoe continue to be ostensibly dissimilar over the course of their professional lives, the titles and plots of some of their novels often seem to engage in conversations with one another. It is worth noticing, for example, how, by her fourth novel, Haywood starts to use proper names as titles, catering to the taste for common lives that Defoe's fictions had fuelled. The author of Robinson Crusoe, on his part, following the desultory reception of the sequels, chooses to foray into the sub-genre of the fictional memoir-one practiced extensively by women writers (Preston, 2003: 104-116). A couple of years after that, he tries out his hand at crafting female protagonists, with his Moll Flanders (1722) and Roxana (1724). Streaks of influence going back and forth can be perceived when reflecting on how Haywood's use of "mistaken identities, masquerade and intricate schemes" that according to a modern scholar "became signature strategies for her" (Backscheider, 2000: 22), are all critical plot props employed by Defoe in his Moll Flanders and Roxana. These, his most famous novels after Robinson Crusoe, point to more than one Haywoodian model. Not only could we read the full title of Defoe's The Fortunate Mistress, Roxana as a parodic spinoff of Haywood's Idalia; or the Unfortunate Mistress (1722), published two years earlier, but it also becomes clear that in this and other novels Defoe introduces what was missing from his inaugural masterpiece: sexual passion. The matter of whether he succeeded, or not, in depicting female experience and psychology is still a contested one among critics (Marsh, 2011: 204-205), but his serious effort can hardly be denied. Like Haywood does in much of her fiction, in Moll Flanders and Roxana Defoe shows the intricacies and unfairness of the politics of courtship and marriage. Rather than laying emphasis on the inner struggles of characters, however - as is the case with Haywood-Defoe focuses on the resemblances of the marriage market with trade in general, and with the economic transactions of the criminal underworld, in particular.

These resemblances do not come as a shock, nonetheless, if one remembers that early novelists were writing in a similar social milieu, while catering to and competing for much the same readership. Moreover, in the 1720s, Defoe had three unmarried daughters still living at home: Henrietta, Hannah, and Sophia (Backscheider, 2008: n. p.), who, we might speculate (without much foundation other than their age and the fact that they were literate women) could have been consumers of Haywood's novels, and, like the protagonists of her stories, liable to face trials to their virtues and reputations in an age when the sexual double standard reigned supreme. In the eyes of some critics, these biographical aspects may provide yet another reason for Defoe's experimentation with female protagonists. 
I want to conclude this paper by letting the works themselves impart their pearls of wisdom on us. First a typical passage from Defoe's Robinson Crusoe:

I learned to look more upon the bright side of my condition, and less upon the dark side, and to consider what I enjoyed, rather than what I wanted: and this gave me sometimes such secret comforts, that I cannot express them; and which I take notice of here, to put those discontented people in mind of it, who cannot enjoy comfortably what God has given them, because they see and covet something that he has not given them. All our discontents about what we want appeared to me to spring from the want of thankfulness for what we have. (Defoe, 1994: 95)

In this episode, readers encounter the voice of an older-and wiser-Crusoe, reminiscing over his past and spelling out lessons for his audience. There is a strong sense of his didactic intent, and a self-awareness bordering on smugness. Now an excerpt from the first volume of Love in Excess:

She had only a thin silk night gown on, which flying open as he caught her in his arms, he found her panting heart beat measures of consent, her heaving breast swell to be pressed by his, and every pulse confess a wish to yield; her spirits all dissolved sunk in a lethargy of love, her snowy arms unknowing grasped his neck, her lips met his half way, and trembled at the touch (Haywood, 2000: 63).

The emphasis here is on the emotions and bodily sensations experienced, something that creates the illusion of immediacy. The omniscient narrator focuses alternatingly on the lovers, Amena and D'Elmont, without providing a clear moral standpoint. The length of the sentence, which is comprised by phrases and clauses separated by an abundance of commas, mirrors the exalted state of the characters and shapes the pace of the sexual encounter taking place. This seems miles away from Defoe.

Now, a passage from his last novel, Roxana:

It happen'd pleasantly enough one Night; his Lordship had staid late, and I not expecting him that Night, had taken Amy to-Bed with me, and when my Lord came into the Chamber, we were both fast asleep, I think it was near three a-Clock when he came in, and a little merry, but not at-all fuddl'd, or what they call in Drink; and he came at once into the Room. Amy was frightened out of her Wits, and cry'd out; I said calmly, indeed my Lord, I did not expect you to-Night, and we have been a little frightened to-Night with Fire: O! says he, I see you have got a Bedfellow with you; I began to make an Apology, No no says my Lord, you need not Excuse, 'tis not a Man-Bedfellow I see; [...] but hark-ye, says he, now I think on't, how shall I be satisfied it is not a Man-Bedfellow? [...] Well, he fell foul of poor Amy, [...] he wou'd know whether Amy was Mr. Amy, or Mrs. Amy, and so I suppose he did (Defoe, 2009: 204). 
We can conjecture that something of the "Great Arbitress of Passion" has found its way into the dispassionate prose of the writer of Robinson Crusoe. Still, if similar in the circumstances narrated, and in their attempt at conveying a sense of presentness, the stories of Roxana and D'Elmont are told from different narratorial perspectives: the one from a first-person witness writing after the fact, the other from that of an unknown speaker outside of the diegesis. Defoe is still very much the moralist he always was, but in his last novel he allows readers to peep into vice more often, in a way that, ironically perhaps, renders his preaching far less effective. Readers of Roxana are often puzzled regarding the moral integrity of the protagonist, nor is it easy to elucidate whether the text condemns her actions in earnest, or covertly endorses them - thus implicitly criticizing the social scaffolding that oppressed women by marketing their sexuality (Mauer, 2004: 364365). Haywood also seems to have derived some narratorial lessons from works like Roxana and Moll Flanders. In novels such as Fantomina (1724) and AntiPamela (1741), for instance, she deals far more in the dichotomies that fascinated Defoe and his readers - not only that of reason versus passion, but also that of passion versus ambition, in which the first must be controlled if the protagonist is to succeed in her determination of acquiring financial independence, social standing, knowledge, or power over men. The novels of Defoe and Haywood endorse the view that human perfectibility is possible by way of ordeal, that individuals could grow in moral and social terms not by following the advice of their elders, but by personal experience - especially of a negative kind. They also suggest that the immersive process of reading fictional lives could count as such an experience - albeit vicarious one. In this respect more than any other, despite all of their ideological, contextual, and personal differences, these two splendid writers close files.

Two central differences ought to be remarked before I bid you, dear patient reader, farewell. The first and most obvious has to do with gender and genre. The subjects that interested Haywood and Defoe, and the way they approached them, are inevitably biased by the roles each of them played in their society on account of their biological sex. After all, authors write of what they know, and what they feel close to their hearts and minds. Given that the overflow of emotion was regarded as part of the female condition (very often the ostensible source of women's problems), it should come as no surprise that Haywood is concerned with depicting emotional perplexity - in both male and female characters. We can see this as a strategy for upholding a position as a woman writer and securing an analogous readership, from whence she could introduce her own personal agendas. Conforming with the expectations of gender roles can similarly explain, in part at least, Defoe's penchant for the crafting of stories about self-reliance, independence, and mobility (even when the characters who embody these notions are women, as in Moll Flanders and Roxana). The titles, plots, and structures of these stories reflect, and at the same time create, an audience. 
The second difference has to do with age. Not only the stage of life each author was moving through when they started writing novels (Defoe 59, Haywood 26) but their generational affiliation, the precise historic period to which each of them belonged. Defoe's eighteenth century was not the same as Haywood's. Born just after the civil wars and coming of age in the transition between the profligate Restoration and the religious and political turmoil of the post-Revolutionary decades, Defoe learned that a person's place in the world was nothing but fixed. Haywood, on her part, reached adulthood and lived the rest of her life during the Hanoverian regime, a period of relative political and religious stability_inside Southern England at least. Over the course of her relatively long lifespan (like Defoe, she lived past her sixtieth year) she witnessed the novel's gradual growth in cultural and moral status. Indeed, we can see her own later production (Betsy Thoughtless being an apt example) engages in the critical debate over the legitimization of prose fiction.

Ultimately, the greatest point of contact between Defoe and Haywood is one that they share with the vast host of authors that struggled to make a name-or simply to survive - in the vibrant and competitive print market of the first half of the eighteenth century in England: an entrenched rivalry in courting the attention of an ever-growing readership. As the quotation from Johnson's essay contained in the title of this one, readers of novels were in the process of growing, not only in numbers but also in age and experience, with every book page that was turned. The belief that writers could introduce life to such an audience must have been an irresistible enticement to creativity.

\section{Bibliography}

BACKSCHEIDER, Paula R. (2000). “The Story of Eliza Haywood's Novels: Caveats and Questions." In Kirsten T. Saxton \& Rebecca P. Bocchicchio (Eds.), The Passionate Fictions of Eliza Haywood. Lexington: Kentucky University Press. 19-47.

BACKSCHeider, Paula R. (2008). "Defoe, Daniel (1660?-1731) Writer and Businessman." In The Oxford Dictionary of National Biography [Online edition].

BACKSCHEIDER, Paula R. (2010). "Haywood, Eliza (1693?-1756)". In The Oxford Dictionary of National Biography [Online edition].

BAKER, David Erskine. (1764). Companion to the Play House ... in Two Volumes. Vol. I. London.

BAllaster, Ros. (1992). Seductive Forms: Women's Amatory Fiction from 1684 to 1740. Oxford: Clarendon Press.

BLouch, Christine. (1991). "Eliza Haywood and the Romance of Obscurity." Studies in English Literature, 1500-1900, 31(3), 535-552. http://doi. org $/ 10.2307 / 450861$ 
Blouch, Christine. (1998). "Introduction.” In Eliza Haywood, The History of Miss Betsy Thoughtless (Christine Blouch, Ed.). Peterborough, Ontario: Broadview Press. 7-19.

Blouch, Christine. (2000). "'What Ann Lang Read': Eliza Haywood and Her Readers.” In Kirsten T. Saxton \& Rebecca P. Bocchicchio (Eds.), The Passionate Fictions of Eliza Haywood. Lexington: Kentucky University Press. 300-326.

Coleridge, Samuel Taylor. (2013 [1818]). “Lecture XI.” Reprinted in Pat Rogers (Ed.), Defoe: The Critical Heritage. Second Edition. London: Routledge. 80.

DAvis, Philip. (1999). "Extraordinarily Ordinary: The Life of Samuel Johnson." In Greg Clingham (Ed.), The Cambridge Companion to Samuel Johnson. Cambridge: Cambridge University Press. 4-17.

Defoe, Daniel. (1994 [1719]). Robinson Crusoe (Michael Shinagel, Ed.). New York: Norton Critical Editions.

Defoe, Daniel. (2009 [1724]). The Fortunate Mistress, Roxana (Melissa Mowry, Ed.). Peterborough: Broadview Press.

DIRDA, Michael. (2019, April 24). "Three Hundred Years Later, Does Robinson Crusoe Hold Up as a Classic?" Washington Post (online). Retrieved on 25 April 2019 from https://www.washingtonpost.com/entertainment/books/threehundred-years-later-does-robinson-crusoe-hold-up-as-a-classic/2019/04/23/7d353524-651c-11e9-82ba-fcfeff232e8f_story.html

English Short Title Catalogue (ESTC). (n.d.). "Search for Love in excess entries Record 7/12.” Retrieved on 26 October 2019 from http://estc.bl.uk/ T75397

Furbank, P.N, \& Owens, W.R. (1998). A Critical Bibliography of Daniel Defoe. London: Pickering and Chatto.

Gildon, Charles. (1719). “A Dialogue Betwixt D__ F__ e, Robinson Crusoe and His Man Friday." In Charles Gildon, The Life and Strange Surprizing Adventures of Mr. D De F . London: J. Roberts. 67-80.

Hartley, Cathy. (2003). A Historical Dictionary of British Women. London: Europa.

Haywood, Eliza. (2000 [1719-1722]). Love in Excess; or The Fatal Inquiry (David Oakleaf, Ed.). Second Edition. Peterborough: Broadview Press.

Hunter, J. Paul. (1990). Before Novels: The Cultural Contexts of EighteenthCentury English Fiction. New York: Norton.

Johnson, Samuel. (1750, March 31). The Rambler. No. 4. Retrieved on 30 September 2019 from http://www.english.upenn.edu/ mgamer/Etexts/johnson. rambler.html

LEE, Sidney. (1891). "Haywood, Mrs. Eliza”. Dictionary of National Biography. Vol. 25. Retrieved on 1 November 2019 from https://en.wikisource.org/wiki/ Haywood,_Eliza_(DNB00) 
MackenZIE, Henry. (1785, June 8). The Lounger, No 20. Retrieved on 3 October 2019 from http://www.english.upenn.edu/ mgamer/Etexts/mackenzie.html

Marsh, Nicholas. (2011). Daniel Defoe: The Novels. Basingstoke: Palgrave Macmillan.

Maslen, K.I.D. (1969). “Edition Quantities for Robinson Crusoe, 1719.” In The Library, 24(2), 145-150.

Mauer, Shawn Lisa. (2004). "Roxana's Amazonian Threat to the Ideology of Marriage." Texas Studies in Literature and Language, 46(3), 363-386.

McBurneY, William H. (1957). "Mrs. Penelope Aubin and the Early EighteenthCentury English Novel." Huntington Library Quarterly, 20(3), 245-267.

OAKLEAF, David. (2000). "Introduction." In Eliza Haywood, Love in Excess (David Oakleaf, Ed.). Second Edition. Peterborough: Broadview Press. 7-24.

OED ONLINE. (2019). "Surprise" (adj) (vb). Oxford: Oxford University Press. Pope, Alexander. (2006 [1729-1742]). The Dunciad in Four Books. In Pat Rogers (Ed.), Pope: The Major Works. Oxford: Oxford's World Classics.

Prescott, Sarah. (2003). Women, Authorship and Literary Culture, 1690-1740. New York: Palgrave Macmillan.

Rawson, Claude. (2014). Swift's Angers. Cambridge: Cambridge University Press. RichETTI, John. (1998). "Popular Narrative in the Early Eighteenth Century: Formats and Formulas." In Richard Kroll (Ed.), The English Novel Volume I: 1700 to Fielding. London: Addison Wesley Longman Limited. 70-106.

RichetTi, John. (2008). “Introduction.” In John Richetti (Ed.), The Cambridge Companion to Daniel Defoe. Cambridge: Cambridge University Press.1-4.

Rodríguez ÁlVAREZ, Argentina. (2017). The Links in the Chain: Imágenes de la mujer en la literatura del siglo XVIII en Inglaterra. Mexico City: UNAM.

Rogers, Pat (Ed.). (2013 [1995]). Daniel Defoe: The Critical Heritage. Second Edition. London: Routledge. 1-30.

RousseAu, Jean Jacques. (1762). Emilius and Sophia: or, A New System of Education. In Two Volumes. London: R. Griffiths.

SAXTON, Kirsten. (2000). "Introduction." In Kirsten T. Saxton \& Rebecca P. Bocchicchio (Eds.), The Passionate Fictions of Eliza Haywood. Lexington: Kentucky University Press. 1-18.

ScotT, (Sir) Walter. (2013 [1834]). "Excerpt from Miscellaneous Works of Sir Walter Scott vol. iv., 248-81." Reprinted in Pat Rogers (Ed.), Defoe: The Critical Heritage. Second Edition. London: Routledge. 66-79.

SEAGER, Nicholas. (2012). The Rise of the Novel: A Reader's Guide to Essential Criticism. Basingstoke: Palgrave Macmillan.

Sharkey, Stephen. (2018, June 21). "An Introduction to Robinson Crusoe". British Library Discover Literature Series. Retrieved on 10 April 2019 from https://www.bl.uk/restoration-18th-century-literature/articles/an-introductionto-robinson-crusoe 
SPEDDING, Patrick. (2004). A Bibliography of Eliza Haywood. London: Pickering and Chatto.

WatT, Ian. (2001 [1957]). The Rise of the Novel: Studies in Defoe, Richardson, and Fielding. Second American Edition. Berkeley: U of California Press.

WHICHER, George F. (1915). The Life and Romances of Mrs Eliza Haywood. Columbia University Press.

White, Jerry. (2013). A Great and Monstrous Thing: London in the Eighteenth Century. Cambridge, MA: Harvard University Press. 